Benda, J.

\section{Všímavost a soucit se sebou}

Praha, Portál 2019, 230 stran

Kniha Jana Bendy Všimavost a soucit se sebou. Proměna emocí v psychoterapii je dobrým průvodcem pro psychoterapeuty a další odborníky, kteří se ve své práci s klienty chtějí zaměřit více na rozvíjení všímavosti a soucitu, pro učitele meditace nebo učitele kurzů založených na všímavosti, kterým může nabídnout širší pohled umožňující dobře propojit duševní a ,duchovní“ složku osobnosti a konečně pro všechny zájemce o rozvíjení všímavosti, laskavosti a soucitu se sebou.

Na knize Jana Bendy považuji za velmi cenné zejména tři věci:

Všímavost a soucit se sebou představuje všímavost v celé její šiři - aby přiblížil všímavost, rozlišuje Benda $\mathrm{v}$ návaznosti na zkušené meditační učitele a tradiční texty tři úrovně všímavosti: 1) „Uvědomit si např., že právě ted' myslíme, a uvědomit si, že můžeme místo myšlení také jen chvíli vnímat - to, jak se naše tělo dotýká židle, na níž sedíme, chut' i vůni kávy, kterou pijeme, zvuky, jež k nám doléhají z okolí, i vše, co vnímáme zrakem..." (s. 22) První úroveň tedy představuje soustředění pozornosti na prrítomnost, a přestože se ještě nejedná o opravdovou všímavost, je tato úroveň důležitým předpokladem rozvoje všímavosti. 2) „Na úrovni 2 bychom všímavost mohli popsat jako schopnost uvědomovat si procesy probíhající v našem těle a $\mathrm{v}$ mysli $\mathrm{v}$ př́itomném okamžiku s postojem smířlivého porozumění a přijeti.“” (s. 24) 3) Na třetí úrovni „si začne meditující postupně uvědomovat tři tzv. univerzální charakteristiky všech všímavě zaznamenávaných procesů (fenoménů), totiž jejich pomíjivost, neuspokojivost a neprítomnost něčeho, co bychom mohli považovat za nějaké trvalé, neměnné Já.“ (s. 29) Přestože tato úroveň vyžaduje velmi intenzivní trénink, lze změny sebe pojímání (směrem k tomu nebrat si věci tolik osobně, neidentifikovat se automaticky s vlastními myšlenkami nebo nehodnotit, nýbrž přijímat prožitky právě takové, jaké jsou) v určité míře sledovat i v terapeutickém procesu, pokud terapeut pracuje s všímavostí.

Druhý bod úzce souvisí s prvním, domnívám se, že Benda ve své knize velmi srozumitelně předkládá Buddhovo učení o ne-já a převádí ho do jazyka psychologie, když ho překládá do polarity narativního nebo konceptuálního Já a prožívaného Já a postoj $\mathrm{k}$ těmto Já pokládá za zásadní. $\mathrm{V}$ rámci zkoumání, co je to Já, rozlišuje 1) Já jako subjekt, „prožívané Já“, které je prostým vědomím toho, že prítomné vjemy, pocity, nálady, myšlenky prožívám Já. Toto já předchází konceptualizaci prožívaného. Na druhé straně je pak možné 2) rozlišit Já jako objekt, „konceptuální Já“, ,autobiografické Já" nebo „narativní Já“, které vzniká myšlením a představivostí. Toto druhé Já je pak v naší mysli častým předmětem hodnocení, posuzování nebo srovnávání. A tomuto Já máme také tendenci připisovat všechnu prožívanou zkušenost a domnělou identitu trvající v čase. Zde se dostáváme $\mathrm{k}$ tomu, čemu Buddha říká ne-já: Já existující jako předmět, $\mathrm{v}$ zásadě neměnný a trvalý v čase, není nic než naše představa, myšlenka nebo př́běh. Zatímco Já jako subjekt je nezbytnou podmínkou duševního zdraví, Já jako objekt, pokud k němu své prožitky př́liš vztahujeme, může stát za řadou problémů. A Benda ve své knize velmi jasně ukazuje, že pokud odmítáme prožívanou zkušenost a chybí-li nám všímavost, máme tendenci si prožitek př́liliš vztahovat ke svému Já (tedy Já jako objektu), což je opět př́činou vzniku maladaptivních emočních schémat, která se projevují zejména jako stud, na které v dalším kroku navazují obranné mechanismy (úzkosti, závislosti, deprese atd). Cestou ke zdraví, vyrovnanosti nebo osvícení, at' už na meditačním polštářku nebo $\mathrm{v}$ rámci terapeutického vztahu, je tedy rozvíjení všímavosti ve všech třech uvedených úrovních, díky čemuž je možné vztah $\mathrm{k}$ vlastnímu Já postupně proměňovat. Tuto část knihy tedy považuji za originální přínos Bendovy 
práce, která se tak může stát dobrým podkladem pro dialog mezi psychologií, psychoterapií na jedné straně a na druhé straně $s$ buddhismem a meditační praxí.

Konečně je Bendova práce vynikajícím úvodem do tématu soucitu se sebou. Soucit (compassion) $\mathrm{v}$ kontextu všímavosti představuje především schopnost neuzavírat se vůči utrpení a vůči tomu, co je těžké, nýbrž to vnímat a přijímat prožitky takové, jaké jsou, a zároveň ochotu a připravenost zmírňovat utrpení a hledat prospěšné způsoby, jak s utrpením zacházet. Jako takový je soucit důležitou protiváhou studu, představuje postoj k sobě, který je podpůrný a vyživující a který vede $\mathrm{k}$ větší vnitřní celistvosti. Přestože $\mathrm{v}$ tradiční meditační praxi je soucit chápán jako přirozený důsledek rozvíjení všímavosti, má rozhodně smysl se jeho rozvíjení věnovat i explicitně, at už v rámci meditační praxe, nebo psychoterapie. Ze srovnání západních meditujících s těmi v Asii se ukazuje, že dobrý základ pro rozvíjení právě soucitu se sebou nebo laskavosti k sobě na Západě často schází, a tak praxe zaměřená čistě na rozvíjení všímavosti může někdy naopak vést $\mathrm{k}$ větší zahleděnosti do sebe nebo odporu vi̊či sobě. Proto $\mathrm{v}$ tomto ohledu opět Bendovu knihu považuji za nesmírně cenný a fundovaný př́spěvek $\mathrm{k}$ tématu soucitu vůbec, protože jasně ukazuje jeho význam v rámci prožívání a vnitřní celistvosti.

Všimavost a soucit se sebou je dle mého názoru výbornou ukázkou toho, v čem Jan Benda vyniká: dokáže poměrně komplexní problematiku zprístupnit jasně a srozumitelně, aniž by zároveň rezignoval na odbornost nebo problematiku nějak redukoval. A zároveň jeho kniha předkládá i řadu praktických cvičení, kterým je možné se věnovat nebo je využít v práci s klienty. Konečně je to také kniha, která nás vyzývá, abychom prohlubovali především vlastní všímavost, protože „... terapeut s meditační zkušeností dokáže vést klienty ke všímavému zaznamenávání procesů prožívaných v prítomném okamžiku a k odhalování dosud neuvědomovaných obranných mechanismů jen do té míry, do jaké je sám schopen všímat si daných fenoménů u sebe samého.“ (s. 33)

Simon Grimmich https://doi.org/10.14712/23366486.2021.3 